\title{
EFFECT OF CONTINUED DAILY INJECTIONS OF OXYTOCIN ON OESTROUS CYCLE LENGTH AND REPRODUCTIVE TRACT MORPHOLOGY IN THE COW
}

\author{
L. E. DONALDSON \\ C.S.I.R.O., Division of Animal Physiology, Cunningham Laboratory, Brisbane
}

(Received 7th March 1968)

\begin{abstract}
Summary. Oxytocin was injected once daily into eighteen Hereford heifers over a period corresponding to several oestrous cycle lengths. Oxytocin was injected at two dose rates (6 or 18 USP units/100 lb liveweight) twice in the day (a.m. or p.m.). Pretreatment cycle lengths were recorded to serve as control cycles. Mean oestrous cycle lengths of $19.4,15.2$ and 11.2 days, respectively, $(P<0.001)$ were recorded in the controls and the groups receiving 6 and 18 units oxytocin. Heifers injected a.m. and p.m. had cycle lengths of 14.8 and 15.7 days, respectively $(P>0.05)$.

Oxytocin produced epithelial cysts in the fimbria of the infundibulum, in the ampulla of the oviduct and in the mucosa of the endometrium of the uterus. There was mild cystic endometrial hyperplasia of the uterus, and occasional cyst formation in the rete ovarii. The epoophoron was dilated and distinct in many ovaries. Large luteinized follicles, apparently cystic, were present at slaughter in four heifers.
\end{abstract}

\section{INTRODUCTION}

Donaldson \& Takken (1968) reviewed the literature pertaining to the effects of oxytocin in cows on oestrous cycle length and corpus luteum net weight, progesterone concentration and total progesterone content. They also showed a decrease in these parameters of corpus luteum (CL) function with increasing amounts of oxytocin injected. At low dose rates (2 USP units/100 lb liveweight) oxytocin, when injected on Days 2 to 5 , stimulated cL function measured on Day 9 (oestrus $=$ Day 0 ) but, as dose or numbers of injections were increased, marked inhibition of CL function occurred. It was postulated that low-dose and short-period injection increased pituitary gonadotrophin release and caused stimulation of the cL. Increase in dose or number of injections either depleted the pituitary of gonadotrophin, blocked the gonadotrophin synthesis or release, or else gonadotrophin synthesis became insufficient to maintain the integrity of the corpus luteum.

Henricks, Oxenreider, Anderson \& Guthrie (1967) reported that systemic progesterone levels were similar in oxytocin-treated normal cows and in oxytocin-treated cows in which the pituitary stalk had been severed. Therefore the oxytocin effect on CL function may include a direct action on the pituitary. 
Küttel (1935) investigated 211 infertile cows and found forty cows with oviduct lesions, fifteen of which had cysts which were associated with chronic salpingitis and could have developed in the epithelial layer as the result of degeneration of epithelial cells. Lombard, Morgan \& McNutt (1950) described the normal morphology of the oviduct of virgin heifers and reported the incidence of oviduct lesions in infertile cows (1951). Mucosal cysts were found in twenty-seven of 103 cows examined on Day 3 of the cycle and nineteen of fifty-one cows examined 20 to 30 days after service. The mucosal cysts varied in size from 30 to $155 \mu$. They were situated in the lamina propria just below the basement membrane of the epithelium and were lined by low cuboidal to columnar epithelium. Dawson (1964) reported similar cysts up to $5 \mathrm{~mm}$ in diameter in twelve of 460 infertile cows. They occurred in any position of the oviduct but mainly in the ampulla and the infundibulum. Dawson reported a significant association between the presence of cysts and nymphomania (hyperoestrogenism) caused by ovarian follicular cysts.

Jubb \& Kennedy (1963) found that noncystic and cystic endometrial hyperplasia in cows was invariably associated with ovarian follicular cysts or granulosa-cell tumours both of which are potential causes of hyperoestrogenism. They reported that increased size and number of endometrial glands and oedema of the stroma caused thickening of the endometrium. The glands lost their normal parallel distribution and showed proliferation and secretory activity and became dilated. Endometritis was often a complication following cystic endometrial hyperplasia.

\section{MATERIALS AND METHODS}

Oxytocin (Posterior Pituitary Extract, Grookes Laboratories, Basingstoke) was injected daily at either 6 or 18 USP units/100 lb liveweight between 09.00 and 10.00 hours or between 16.00 and 17.00 hours Injections began the day after oestrus, and continued for between 30 and 68 days.

Twenty virgin Hereford heifers were used; two received no treatment. Six were allocated to the high dose of oxytocin and twelve to the low dose, half of each group being injected at each time of the day. They were examined for oestrus at least twice and usually three times a day. Pretreatment oestrous cycle lengths were recorded to serve as control cycles. The ovaries of the heifers were palpated after oestrus to detect ovulation and corpus luteum formation. Five heifers from the high dose and seven heifers from the low dose were slaughtered on Day 1 or 3 after their last oestrus and their reproductive tracts removed. Three heifers from each group were ovariectomized. Pieces of the reproductive tracts and the ovaries were fixed in Bouin's solution, sectioned at $6 \mu$ and stained with haematoxylin and eosin. The pituitaries were stained with PAS-orange G.

\section{RESULTS}

The results of daily injections of oxytocin are given in Table 1 . There was a response in cycle length to the oxytocin treatment. The pretreatment cycle lengths averaged 19.4 days and the groups received 6 units and 18 units of 
oxytocin 15.2 and 11.2 days, respectively, $(P<0 \cdot 001)$. There was no effect of time of injection or interaction between dose rate and time of injection. The heifers continued to cycle during these treatments. One heifer had seven cycles, and twelve had three or four cycles, three had two cycles and two had one cycle. As judged by rectal palpation, ovulation and corpus luteum formation occurred normally except on one occasion each in each of two cows during 5- and 6-day cycles, but laparotomies were not performed to confirm these findings.

Epithelial cysts, up to $7 \mu$ in diameter, were found in the fimbria of the infundibulum and ampulla of the oviduct (Pl. 1, Figs. 1 and 2). Two larger cysts $(22 \mu)$ were seen in one heifer. These larger cysts resembled those described by Lombard et al. (1951) as being in the lamina propria. The histogenesis of the

TABLE 1

THE MEAN EFFEGT OF DAILY OXYTOCIN INJEGTIONS ON OESTROUS GYGLE LENGTH IN HEIFERS (DAYS)

\begin{tabular}{|c|c|c|c|c|}
\hline \multirow{2}{*}{\multicolumn{2}{|c|}{$\begin{array}{l}\text { Dose of oxytocin } \\
(\text { USP units } / 100 l b)\end{array}$}} & \multicolumn{2}{|c|}{ Time of injection } & \multirow{2}{*}{ Total } \\
\hline & & a.m. & p.m. & \\
\hline 0 & $\begin{array}{l}\text { Pretreatment cycles } \\
\text { Mean } \\
\text { S.E. (mean) }\end{array}$ & $\begin{array}{r}12 \\
19 \cdot 5 \\
0 \cdot 7\end{array}$ & $\begin{array}{l}14 \\
19 \cdot 4 \\
0 \cdot 4\end{array}$ & $\begin{array}{l}26 \\
19 \cdot 4\end{array}$ \\
\hline 6 & $\begin{array}{l}\text { No. cycles } \\
\text { Mean } \\
\text { S.E. (mean) }\end{array}$ & $\begin{array}{l}13 \\
14 \cdot 5 \\
2 \cdot 0\end{array}$ & $\begin{array}{l}18 \\
15 \cdot 8 \\
1 \cdot 5\end{array}$ & $\begin{array}{l}31 \\
15 \cdot 2\end{array}$ \\
\hline 18 & $\begin{array}{l}\text { No. cycles } \\
\text { Mean } \\
\text { S.E. (mean) }\end{array}$ & $\begin{array}{l}11 \\
10 \cdot 2 \\
1 \cdot 0\end{array}$ & $\begin{array}{l}14 \\
12 \cdot 1 \\
1 \cdot 4\end{array}$ & $\begin{array}{l}25 \\
11 \cdot 2\end{array}$ \\
\hline \multicolumn{2}{|c|}{$\begin{array}{l}\text { Total no. cycles } \\
\text { Mean }\end{array}$} & $\begin{array}{l}36 \\
14 \cdot 8\end{array}$ & $\begin{array}{l}46 \\
15 \cdot 7\end{array}$ & $\begin{array}{l}82 \\
15 \cdot 3\end{array}$ \\
\hline
\end{tabular}

By analysis of variance the residual mean square was 24.041 and the variance ratio for time of injection 0.88 and dose 17.86 . The dose effect was highly significant.

small cysts could not be discerned and it was not possible to decide whether these small cysts could develop into the larger cysts. Epithelial cysts up to $8 \mu$ in diameter were also seen in the mucosa of the endometrium of the uterus (Pl. 1, Fig. 3). Their histogenesis appeared to be associated with swelling and lysis of individual cells.

Gysts appeared in most sections of the infundibulum and ampulla of all heifers examined, but not in the isthmus. However, cysts were not seen in the uterine mucosa of all sections nor in all animals. It was not practicable to record the number of cysts present. Serial sections confirmed that the structures described in the oviduct and mucosa of the endometrium were in fact cysts (usually round) and not, in the case of cysts in the uterine mucosa, openings of endometrial glands through the mucosa.

The uterine endometrium showed varying degrees of mild hyperplasia, with hypertrophy of the blood vascular system, oedema of the stroma and dilation of the endometrial glands (Pl. 1, Fig. 4). 
The rete ovarii appeared cystic in three heifers. The cysts were lined by cuboidal epithelium. The epoophoron was dilated and distinct in seven heifers.

Cystic follicles were seen in four heifers. These follicles ranged in diameter from 15 to $20 \mathrm{~mm}$. When slaughtered on Day 1, one heifer had two large follicles. The theca interna was heavily luteinized, and the granulosa was degenerated in one follicle. The other follicle and those in two other heifers with one cystic follicle had a moderately luteinized theca interna and granulosa layers. These heifers could have been slaughtered before normal ovulation time. Another heifer had a degenerating cystic follicle heavily luteinized in the theca interna and undergoing degeneration. There was a fresh ovulation on the same ovary. Nothing abnormal was detected in any of the corpora lutea examined.

The gonadotrophin-producing cells of all anterior pituitaries were degranulated. It was impossible to associate dose rate of oxytocin with the number or degree of severity of pathological lesions.

Normal oestrous cycle lengths were recorded and no abnormalities were detected in the reproductive tracts of two untreated heifers fed and managed with the experimental animals and slaughtered during the same period.

\section{DISCUSSION}

The maintenance of cyclical activity under continued oxytocin treatment suggests that oxytocin affects the release rather than the synthesis of pituitary gonadotrophin. Low dose rates for $\mathbf{4}$ days early in the cycle caused cL stimulation, whereas increase in dose rate or number of daily injections resulted in a reduction in cL function (Donaldson \& Takken, 1968). Oestrus and, usually, ovulation occurred following regression of the CL during oxytocin treatment indicating that the pituitary was able to provide the ovulatory surge of LH even during treatment.

The lesions in the ovaries, oviducts and mucosa of the uterus have not been described previously and are suggestive of continued oestrogen stimulation. The literature cited in the introduction provides differential diagnoses, and the suggestion that this type of lesion can be caused by oestrogen. Thus, oxytocin may cause increased ovarian synthesis of oestrogen. The endometrium may have been in an active secretory phase, and the possibility of production of a uterine luteolytic factor cannot be excluded. Attempts to identify such a factor in oxytocin-treated heifers have been unsuccessful (Hansel, personal communication).

Oxytocin has been shown to affect ovarian function through central (pituitary, Donaldson, Hansel \& Van Vleck, 1965; Donaldson \& Takken, 1968) and

\section{EXPLANATION OF PLATE 1}

Fig. 1. An epithelial cyst in the fimbria of the infundibulum of the oviduct.

Fic. 2. Numerous epithelial cysts in the infundibulum in the region of its attachment to the hilus of the ovary.

Fig. 3. Epithelial cysts in the mucosa of the endometrium of the uterus.

Fig. 4. Cystic endometrial hyperplasia of the uterus. 
PLIIE 1
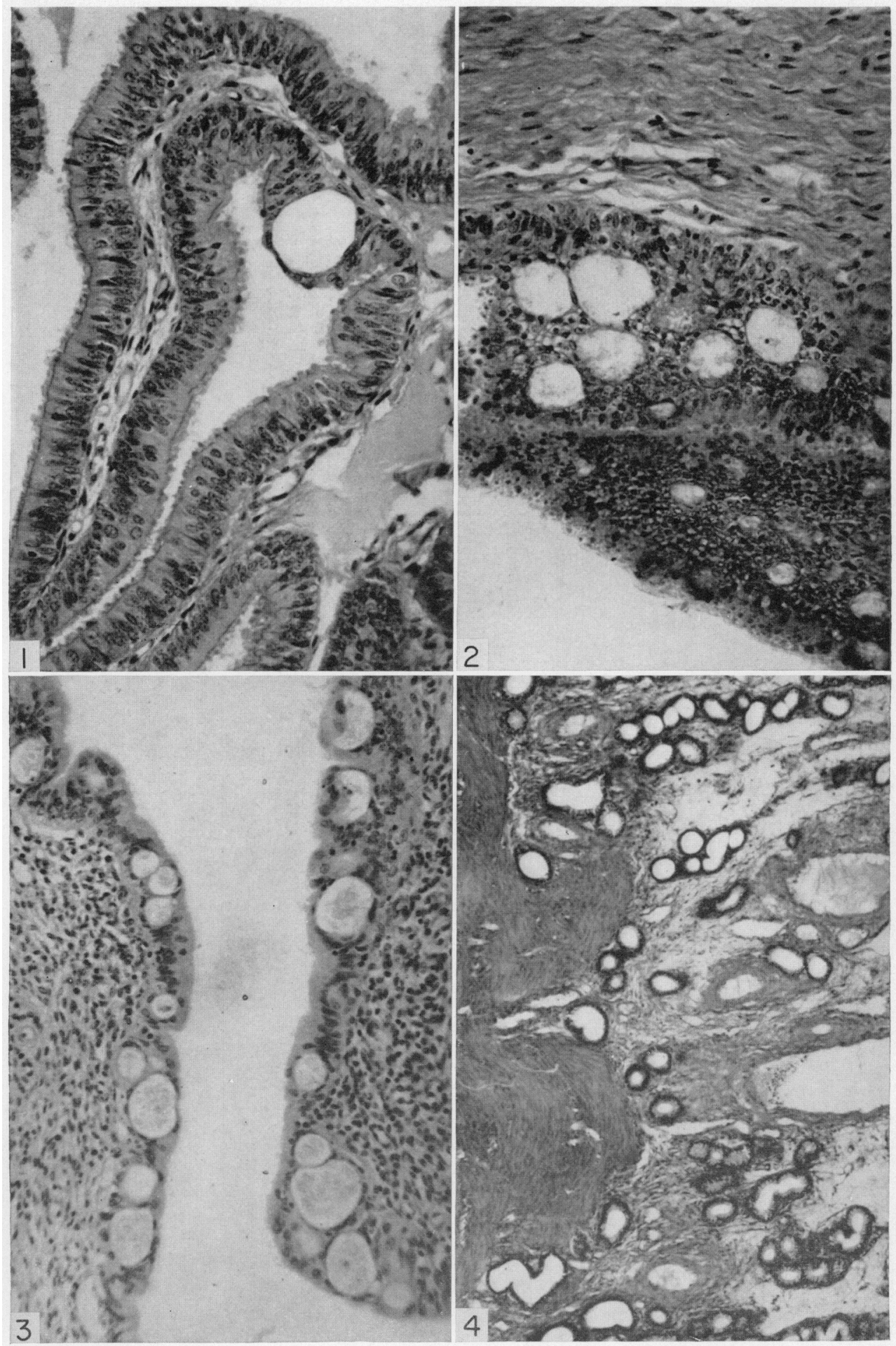

(racing f) 262) 
local (uterine, Ginther, 1967), control mechanisms. However, as yet, no normal physiological role in ovarian function has been ascribed to oxytocin. This possibility deserves serious consideration in the light of the quantities of oxytocin produced in the hypothalamus and stored in the posterior pituitary, and the effects of oxytocin on ovarian function in experimental situations.

\section{ACKNOWLEDGMENTS}

The assistance of $\mathrm{Mr} \mathrm{A}$. Takken and $\mathrm{Mr}$ J. Leonard is gratefully acknowledged as is that of the Australian Meat Research Committee for partially financing this experiment.

\section{REFERENCES}

Dawson, F. L. M. (1964) Fertility relationships with cystic conditions in cow oviducts. Int. Congr. Anim. Reprod. 5, Sect. 4, 182.

Donaldson, L. E., HANSEL, W. \& VAN Vleck, L. D. (1965) Luteotrophic properties of oxytocin induced luteal inhibition in cattle. F. Dairy Sci. 48, 331.

Donaldson, L. E. \& Takken, A. (1968) The effect of exogenous oxytocin on corpus luteum function in the cow. J. Reprod. Fert. 17, 373.

Ginther, O. J. (1967) Local utero-ovarian relationships. F. Anim. Sci. 26, 578.

Henricks, D. M., Oxenreider, S. L., Anderson, L. L. \& Guthrie, H. D. (1967) Progesterone in systemic and ovarian venous blood and corpora lutea of cycling, hypophysial stalk sectioned, stalk sectioned hysterectomized and stalk sectioned oxytocin treated cows. Fedn Proc. Fedn Am. Socs exp. Biol. 26, 625.

JusB, K. V. F. \& Kennedy, P. C. (1963) Pathology of domestic animals. Academic Press, New York.

KüтTEL, E. (1935) Beiträge zur pathologischen Anatomie des Eileiters beim Rind und beim Schweine. Auszug aus der Inauguraldissertation Györ.

Lombard, L., MORGAN, B. B. \& MCNUTT, S. H. (1950) The morphology of the oviduct of virgin heifers in relation to the estrous cycle. F. Morph. 86, 1 .

Lombard, L., Morgan, B. B. \& McNutr, S. H. (1951) Some pathologic alterations of the bovine oviduct. Am. F. vet. Res. 12, 69. 